\title{
26 Gender, migration and globalisation: an overview of the debates Sabrina Marchetti
}

What does it mean to talk about 'gender' in relation to migration? When confronted by this question, scholars and students who already know what 'migration' means are puzzled by how they should put this together with an equally vast realm of concepts and facts - those that consider what gender is. Or, to be more precise: what gender does. For this purpose, in this chapter I am providing an overview of what gender does to migration, illustrating some of the ways in which taking a gender perspective changes the way we understand the link between migration and globalisation, and how gender-based differences and inequalities affect (and are affected) by global migrations.

I will do this, first of all, by introducing the relevance of gender issues to migration debates, and thus speak of the 'feminisation of migration'. This, I contend, can be seen at a quantitative and qualitative level. Therefore, the chapter delves into a specific dimension of the feminisation of migration by taking the case of domestic and care workers to discuss issues such as the 'international division of reproductive labour' and the 'global care chain'. In the second part of the chapter I offer an historical overview of the scholarship that has developed around the gender-migration-globalisation nexus in the last 40 years. At the end, I outline other possible directions for research in this field.

\section{WHAT DOES GENDER DO? THE FEMINISATION OF MIGRATION}

The overlap between the questions of gender, migration and globalisation gives rise to a complex discussion whose key terms have many different definitions and where facts are interpreted in often contrasting ways. My suggestion is to approach this complexity by distinguishing between a quantitative and a qualitative dimension in which gender and global migrations enter in relation.

At the quantitative level, the main questions are: how many women are migrating? How many men? And how have their numbers changed over time? It is important to emphasise how, at this level, gender is considered to speak of the binary division between men and women as based on a set of biological and physical features differently ascribed to male and female models, thus overlooking cases of transgender or intersexual people and with no distinctions on the basis of age, sexual orientation and so forth. At this level, what is of interest are usually the numbers of migrant women, their relative proportion to those of men, their nationalities and then, in more detail, what are their destinations, occupations, marital status and so on.

At this quantitative level, we speak of the 'feminisation of migration' to describe the increase in the percentage of women in international migration - which, for instance 
in the period $1960-2000$, rose from 46.6 per cent to 48.8 per cent of total international migrations (United Nations 2006). ${ }^{1}$ These percentages can be disappointing for those who ask what is the 'novelty' in the migration of women per se. Women in fact have always migrated in significant numbers, especially in rural to urban and circular migrations, in some regions of the world more than others (Ellis et al. 1996; Marx-Ferree 1979; Gabaccia 1994; Pessar 1984; De Clementi 2002; Radcliff 1991). The novelty, however, is at a deeper level: women are increasingly migrating as solo or pioneer migrants, in long-distance movements, as workers and thus with the function of breadwinner for their households. In other words, women are joining migrant men in these traditionally masculinised types of migration. For this reason, it is important that quantitative approaches to migration are not limited to the general question 'how many women migrate?' but go further by asking: how far women go; if they go alone or follow their husbands or other men; and what is the purpose of their migration - if it is for reunification, independent work, for remittances and so on. This awareness invites us to move towards the second dimension of the relation between gender and migration.

The qualitative dimension of the feminisation of migration stems from a more complex view of gender as the ensemble of norms and principles that regulate people's lives along two opposite models - male and female - that are socially and culturally constructed. Although often perceived as fixed and natural, gender models are instead a terrain of continuous negotiations: what is the proper behaviour for men and women; what are they expected to do and achieve; what is their role in their household and society? Indeed, gender models are strongly contextual, and vary from place to place and at different times in history. Of course, these also intersect with other (socially constructed) differences that apply to people's experiences - such as class, race and age - which further complicate the determination of what the functioning of gender is in each context.

At this level, the experience of migrants offers the example of different attitudes and outcomes. Assuming a context of departure where dominant gender roles are set along the opposition 'women as dependent wives and sacrificing mothers' v. 'men as breadwinner husbands and fathers', one may notice how often migrants enact an emancipation from this - as in the example of migrant women becoming breadwinners. However, migration can also disclose a regressive element, with the replication (if not worsening) of expectations tightening to traditional gender roles. Therefore, for those interested in this qualitative dimension of the feminisation of migration, the important questions are: how does migration change gender roles, and do gender expectations affect migrants' experiences? In other words: how does the migration-gender nexus affect the negotiation of duties, expectations, possibilities and opportunities that apply differently to men and women along their migratory experience?

These questions together may lead to a more general point which, paraphrasing Susan Moller Okin (1999), is summarised by the formula 'is migration good for women?' Scholars are divided between those who look positively at migration as an opportunity to escape oppressive marriages, gain economic independence by becoming a self-sufficient earner and improve one's social position vis-à-vis the context of origin, which is usually achieved by contributing with remittances, and with philanthropic interventions for the wellbeing of families and the development of local communities (Bonifacio 2012; Boserup and Kanji 2007; Chant 1992; Piper 2013). For transgender and gay people, migration has been seen as a chance to freely express their sexual orientation and even, in some cases, 
escape persecution of homosexuality in their countries (Cantú et al. 2009). Parreñas (2001), for example, commented on how such improvements could justify the decision to migrate by those who, coming from middle-class educated backgrounds, will experience a strong downgrading through low-skilled and stigmatised jobs in the country of destination. Conversely, migration is seen as a source of vulnerability for people, and especially women. The emphasis here is on the dangers that migrants can encounter on their journey at the hands of traffickers and smugglers - such as being exposed to sexual violence, forced pregnancies and being channelled into prostitution and slavery-like work (Anderson and Andrijasevic 2008; O'Connell Davidson 2005). These studies depict migrant women and girls as being at greater risk of physical and psychological violence than men, especially when their migration happens for arranged marriages or when the women flee their countries as refugees. Working migrant women are also seen as particularly vulnerable to the abuses they can suffer in their workplace, especially due to the isolation that characterises private domestic and care work (Anderson 2000). Finally, the positive view on women's improved economic position, thanks to their new earning capacity, is challenged by studies that show how sending remittances is often felt as an obligation by migrant women, and as a cause of distress and self-deprivation from which migrant men are more easily released (Basa et al. 2012; Boserup and Kanji 2007; Kabeer 2003).

In conclusion, one can look at how gender does change the experience of migration; for example, how it makes it into an empowering or weakening experience at the individual level and how people can navigate that. Moreover, at the subjective level, feminist geographers have also argued that thinking about gender changes the way we understand the relationship between identity and place, thus also the way we conceptualise people's mobility across space (Massey 1994; McDowell 1999; Silvey 2004). Likewise, scholars have elaborated on women's relationships and strategies to sustain their gendered commitments in transnational households (Salih 2003; Baldassar 1997; Degiuli 2016).

However, I shall go further and say that this is not the only meaning of the feminisation of migration in its qualitative dimension. There is another meaning which goes beyond individual experiences and questions how the social construction of gender - and the inequality that it entails (see Parreñas 2009) - can be seen at the macro level as an organising principle of contemporary migrations, thus affecting their features as well as the way we analyse and interpret them. This macro dimension will be discussed in the next section.

\section{THE HISTORICAL DEVELOPMENT OF 'GENDER AND MIGRATION' SCHOLARSHIP}

It is difficult to talk about developments in the field of 'gender and migration' without taking into consideration what was happening in the two parent fields of Women's Studies and Migration Studies. This is further complicated by the fact that both Women's and Migration Studies were not considered to have the authority of other research fields until very recently, but were considered of lesser value than traditional academic research. It is probably only due to the compelling transformations that have happened in the world in the last decades, with migrants and women as protagonists, that have slowly convinced academia to make room for these studies.

Therefore, in order to describe the evolutions in this research field, it is important to 
look at how, at different times, external events created momentum for gender and migration issues and for policy-oriented research on this subject. It is also important to look at the efforts made by (mainly women) sociologists, geographers, historians, anthropologists and so on who, in their respective disciplinary fields, have tried to push new research agendas on these topics, thus contributing to building the interest they receive today.

In this light, the special issue of the International Migration Review edited by Mirjana Morokvaśic in 1984 is rightly considered the first milestone of this debate. The articles in this volume reflect the number of studies developed by the late 1970 s focusing on the experience of migrant women. Most of the articles look at migrant women who arrived in Australia, Northern America or Europe over a large timespan (from the nineteenth century onwards) in an attempt to understand their conditions and participation in the labour market compared to migrant men and non-migrant women. It is important to note how most of the authors are social historians and labour sociologists: this scholarship was heavily influenced by the Marxist-oriented debate of the 1970s on the role of migration in the capitalist expansion. In fact, the title of Morokvaśic's introduction, 'Birds of passage are also women', refers to the expression 'migrants are birds of passage' used by Michael Piore (1980) in his analysis of the exploitation of the migrant workforce in market economies. This scholarship was also importantly influenced by the interest stirred in the 1960s-1970s regarding the experiences of groups usually far from the public eye - typically poor people, migrants and women - whose perspective was emphasised with the use of oral history and ethnographic methods.

These earlier scholars are literally drawing attention to a 'hidden' phenomenon, if we consider that comprehensive data on the number of women migrants were not available until very late: the UN Population Division first released data on women's migration in 1998. Yet, the high number of women was evident when looking at their presence as labourers, as well as wives who rejoined their husbands - this case being especially important in those European countries like Germany, the Netherlands and Denmark which had closed to labour migration in the 1970s and were receiving migrants only for family reunification.

Another important turn in this scholarship happens in the 1980s, with the encounter between migration theory and feminist and black theories on reproductive work and multiple oppressions. Throughout the 1970s and 1980s, several scholars in North America and Europe had elaborated on women's oppression and the function of reproductive work, as I have illustrated earlier. This had fostered a number of studies on (paid and unpaid) domestic work and other feminised occupations (Dalla Costa and James 1973; Oakley 1975), as well as attention for the role of women in developing countries (Benería 1979). Black feminist scholars had also demonstrated how this work was unequally distributed between white and black women in the history of the United States (Rollins 1985). This literature first 'met' the migration debate with some fundamental studies on the insertion of migrant women in paid domestic work, taking the example of Mexican and Latin America women employed in the US domestic work sector (Romero 1992), as well as Irish and Asian women (O'Leary 1996), that could be compared to the case of African American women traditionally active in that sector.

The 1980s is also the beginning of the debate on intersectionality, which was loudly echoed in the newly shaped field of Women's Studies, as well as in Ethnic Studies, in the US context (McCall 2005; Davis 2008). 'Intersectional thinking' rapidly spread to Europe, 
where it informed new approaches to the experience of migrant women, with particular attention on their narratives of interlocking oppressions. This brought attention to migrant women as being vulnerable subjects in the context of a dominant discourse on multiculturalism and assimilationist integration (Anthias 1992; Dwyer 1999). Here again, this scholarship aimed to bring to the fore of mainstream academia the condition of migrant women, which had been largely neglected.

With the 1990s, we enter in a new phase of interest in women's migration. This is due, in part, to the collapse of the Soviet Union and consequent large-scale migration of women from East to West Europe, very often employed in domestic, care and sex work (Ferreira et al. 1998; Solari 2010; Vianello 2014). Even more evident was the relevance of gendered global diasporas, most obviously in the case of Filipino women who come into sight as the quintessential protagonists of what I earlier described as the 'global care chain' (Parreñas 2001; Pratt 2012). Also worth noting is the impact of the UN World's Women Conference held in Beijing in 1995, which is widely acknowledged as inaugurating a new phase of interest in gender issues in a 'global governance' perspective (Meyer and Prügl 1999).

As an outcome of this achieved awareness, the years 1999-2001 see the publication of new ground-breaking monographs by Jaqueline Andall (2000), Rhacel Parreñas (2001), Bridget Anderson (2000) and Pierrette Hondagneu-Sotelo (2001), as well as the edited volume by Janet Momsen (1999). They are followed, in 2002, by the volume Global Woman: Nannies, Maids and Sex Workers in the New Economy, edited by Barbara Ehrenreich and Arlie R. Hochschild, that collects the works of new emerging authors in this field. In my view, the importance that these volumes (coincidentally published within such a short time) had for the entire following decade of research on gender, migration and globalisation - inaugurating a period of emphasis on migrant domestic and care work - is quite telling. Also, within the same period, important journals in Sociology, Geography and Women's Studies devote special issues to migrant women, consecrating the cross-fertilisation between the fields of studies, as in the case of American Behavioral Scientist (edited by Pierrette Hondagneu-Sotelo in 1999), Identities: Global Studies in Culture and Power (edited by Sarah J. Mahler and Patricia Pessar in 2001) and, finally, Signs: Journal of Women in Culture and Society (edited by Amrita Basu et al. in 2001).

The next decade sees an incredible increase in the number of international scholars focusing on the issues of migrant domestic and care work who share a solid corpus of methodological and theoretical tools, highly interdisciplinary, which they are able to adapt to the analysis of migrant women's experiences in different parts of the world, and at different times. Important examples of this scholarship are represented by Helma Lutz (2011), Rosie Cox (2006), Raffaella Sarti (2002), Sarah van Walsum (2011) and Fiona Williams (2012) for the European context. Outside Europe, among many others, it is important to mention Pei-Chia Lan (2006) for Southeast Asia; ${ }^{2}$ Raka Ray and Seeming Qayum (2009) for India; and Gioconda Herrera (2013) for Latin America, as well as Marina de Regt (2009) on Yemen and Gül Özyeğin (2010) on Turkey. Also, migration for sex work becomes an important topic, although quite separate from the one of migration in domestic and care work (see Andrijasevic 2010; Agustín 2007; Mai 2013).

However, since the late 2000s a new era emerged for debates on gender and migration, during which we can observe quite opposite tendencies. On one side, we observe the actual mainstreaming of both issues: gender and migration move out of their niches and attract growing interest from scholars across disciplines and fields of study. Gradually 
integrated into research agendas of other relevant fields, gender and migration are now a core element in a range of disciplines from the social sciences. The question of migrant domestic workers, for instance, is no longer an isolated topic, but becomes an ingredient of wider analysis on labour, ageing, health and so forth (Ambrosini 2013; Da Roit 2010; Timonen 2008). This is creating very interesting terrains of analysis today, with scholars from different backgrounds elaborating new gendered perspectives on racism, globalisation, economics and welfare - some of which have been mentioned in the previous pages.

On the other side, feminist scholars, especially the pioneers in this field mentioned earlier, are reflecting on the outcome of all these years of flourishing research. In 2006, the International Migration Review dedicated another milestone issue to gender and migration. In their introduction, the editors sarcastically ask: 'Another special issue on gender? Haven't there been enough of those?' (Donato et al. 2006: 3). In a self-reflective mood, several scholars are looking partially disappointed about what has been achieved, seen as a 'glass half-full', and say that more effort is needed to reach more ambitious aims.

\section{GENDERING MIGRATION: THE GLOBALISATION OF DOMESTIC AND CARE WORK}

'Global transformations are also gendered transformations ... gender is an important factor influencing migration today and this recognition has spurred a range of empirical studies, theorisation and policy measures' (Kofman and Raghuram 2015: 11). After more than 40 years of scholarship on the relationship between gender and migration, Eleonore Kofman and Parvati Raghuram can make such a statement without fear of being criticised for overestimating the role of gender as an explanatory factor of migration and globalisation. While in the next section I will provide an overview of the different steps in the scholarship that have led to this awareness, in this section I would like to discuss some of the fundamental tenets behind their general argument that 'global transformations are also gendered transformations'.

In their introduction the International Handbook on Gender, Migration and Transnationalism, Laura Oso and Natalia Ribas-Mateos (2013) summarised the two dimensions in which gender is ingrained in the organisations of global migrations. On one hand, we see that women and men are differently employed at the sites where industrial production was delocalised from the centre to the peripheries. The international division of industrial production, in fact, shows gender-segregated sectors of employment, with women and girls working more often in what Bridget Anderson (2000) calls the 3D jobs: dangerous, demanding and demeaning. This tendency was already clear in 1984 when Mirjana Morokvaśic edited the first special issue of the International Migration Review on the relationship between gender and migration. The articles that composed the volume illustrated the painful conditions of women working in fields, factories or in their houses (as home-workers) in the transnational assembly line of food, garments or electronic products. Assumptions about different skills and bodily characteristics between men and women, as well as their different conditions during the life cycle, suggest in a way that the "women from the peripheral zones ... represent a ready-made labour supply which is, at once, the most vulnerable, the most flexible and . . . the least demanding workforce' (Morokvaœic 1984: 886). Such gender-based differentiation affects peripheral migrations, 
within same countries or same regions, from impoverished areas towards nearby areas where newly delocalised production demands their labour (Enloe 1989). This explains the participation of women and men in distinctive types of agricultural work, also on a seasonal basis, and migrant men's participation in construction, mining or the metal industry versus women's employment in textiles, electronics and the food industry.

On the other hand, the focus is not on the delocalised agro-industrial production in peripheral economies, but on what happens in the advanced industrialised countries. These become receivers of migrant workers for all the sectors that are not (yet) delocalised and which demand cheap and flexible labour. Importantly, these include 'domestic service, catering, personal and sex work [that] cannot be exported in the same way as industrial activity' (Oso and Ribas-Mateos 2013: 10), and where migrant women are massively employed. Following on, Saskia Sassen (2000), Thanh-Dam Truong (1996) and Oso and Ribas-Mateos thus identify a second channel of the North-South transfer of work that runs parallel, although in the opposite direction, to the one described above for agro-industrial labour.

The relevance of care, domestic and sex work for the employment of all women, not only migrants, is widely acknowledged (Hoerder et al. 2015; Schrover and Yeo 2011). Recent data from the International Labour Organization (ILO 2013) have estimated the number of people who work in other people's private households as cleaners or care works at 52.6 million; 83 per cent of these people are women or girls, while one in every five domestic workers is a migrant. These estimates attest to the importance of domestic and care work as a key to employment for women at the global level. This labour sector is particularly important in the global South: one in four female wage-workers is a domestic worker in Latin America and the Caribbean, and almost one in three in the Middle East. In India, there are about 4 million domestic workers. Some countries are impacted by this phenomenon as their female population leaves to take up domestic work abroad, as is particularly the case in Asian-Pacific countries, Eastern Europe and South America. It would be important to have similar estimates on the number of sex workers in the world and what proportion of them are migrant women. It goes without saying that they are indeed an important group in this category. The same could be said for migrant women who are occupied in jobs that have strong gender connotations, such as cooking, cleaning and nursing.

It is important here to expand on the exact meaning of cleaning, caring and sex work for women. Feminist scholars define these tasks (whether paid or unpaid) as social reproduction; that is, simply put, the labour that is necessary for the reproduction of the labour force (Kofman 2012). This means preparing food, mending clothing, cleaning homes, giving birth and raising children, assisting elderly and sick people and all other tasks that are functional to people's prosperous living - day after day, and across generations, at the material and symbolic levels (Petersen 2003). If in traditional economies these tasks were accomplished, almost in their totality, inside the household by (unpaid) female family members (while males were occupied in productive work), in contemporary economies, increasing portions of these activities are commodified: meals prepared by professional cooks can be bought in restaurants; elderly people are assisted by paid care-givers in nursing homes. This is a growing and seemingly unstoppable process, with always new intimate and private tasks, especially those related to different types of body-work, being incorporated into the market (Boris and Parreñas 2010; Wolkowitz 2006). It makes 
scholars talk of a 'care economy' (Folbre 2001; Zelizer 2009) characterised by the (often informal) employment of a precarious workforce with strong gender, race, class-based connotations (Sassen 2002).

The imbalance affecting the distribution of reproductive tasks changes depending on how we look at it: from a gender perspective, women do take up a bigger share than their male counterparts; but it also true that between women, reproductive work is more often done by black or migrant women, and in general women who are from minority and racialised groups (Rollins 1985; Nakano-Glenn 2002; Palmer 1989). In most industrialised countries, it has been especially noted how citizenship is crucial for understanding the large numbers of undocumented migrants (mostly women, but also men) who work in house cleaning, elderly care, catering and restaurants. Private employment of domestic and care workers, in particular, is negatively impacted by existing migration policies that make the regular employment of migrants difficult (Triandafyllidou 2016; Ong 1999). In conclusion, the social stratification between the subjects involved in reproductive work contributes to the under-valuation of these jobs as far as these are considered 'naturally' assigned to the most vulnerable and stigmatised subjects in each context (GutiérrezRodríguez 2010; Lan 2006).

In 2000, Rhacel Parreñas introduced the 'international division of reproductive labour' formula to expand the view from its 'racial' division (Nakano-Glenn 2002) to the global level. Parreñas finds it important to emphasise how this work is generally unequally distributed along a 'three-tier transfer of reproductive labour in globalization between the following groups of women: (1) middle-class women in receiving nations, (2) migrant domestic workers, and (3) Third World women who are too poor to migrate' (Parreñas 2000: 560). In her study on the Filipino diaspora, she found that the same Filipino women employed in Western households to care for children and elders are delegating their own family commitments to other women: other female family members but also other women, from poorer backgrounds, whom they pay a salary of about USD 40 per month out of the USD 1000 they earn abroad - for doing the same job (Parreñas 2009). In this view, globalisation is the scenario against which reproductive work is divided and passed on from one woman to another, who is in a less privileged position.

The same idea has been taken up by Arlie Russell Hochschild, who used the catchier expression 'global care chain' to suggest the existence of a bond between women from different parts of the world who have to come to terms with the caring duties placed on their shoulders by gender inequality. For Hochschild, this produces a 'care drain' from the global South to the global North due to the 'the importation of care and love from poor countries to rich ones'. It is important to notice how, in her view, the focus is not any more on 'reproduction' in general but on a specific ingredient of reproductive labour: 'love', which she sees as an 'unfairly distributed resource-extracted from one place and enjoyed somewhere else' ((Hochschild 2002: 17, 22).

Along the lines of Hochschild's argument on 'care drain', a plethora of studies has developed on the question of the lack of attention suffered by the children of international migrant women (Parreñas 2005; Pratt 2012). However, authors have also warned against this emphasis on 'care' as a substitutive term for what was called 'reproductive work' in previous literature. Eleonore Kofman, in particular, considers 'care' a quite narrow concept, and still prefers to use the more powerful notion of social reproduction in order to explain the relationship between gender, migration and globalisation despite 
the criticisms that the notion of 'reproduction' has received in the past. In her view, the globalisation of social reproduction is sufficient to explain the interconnection between what happens in a wider 'landscape of activities and sites'. Moreover, talking about reproduction makes it possible 'to connect supposedly disparate circuits of migration, in particular labour, family, and education' (Kofman 2012: 144). It is important, indeed, not to lose sight of the wider picture within which the labour migration of domestic and care workers is happening. For example, increasing numbers of women also migrate for marriage: whether these are wives reuniting with their husbands and children or are foreign spouses marrying Western men who are strangers, this migration ultimately serves the reproduction of families and societies on a transnational scale (Douglass 2006). For Kofman (2012), only when speaking of the 'globalisation of social reproduction' can we understand the linkages between apparently different phenomena such as migration for domestic, care and sex work, international adoption, the use of remittances for local development and the settlement of pensioners in low-income countries to save resources, as well as households' decisions to send children abroad for study to increase their cultural capital (see also Douglass 2006; Constable 2016).

Of a different opinion are authors like Nicola Yeates (2004: 370), who finds that the concept of the global care chain 'captures the significance of transnational care services and the international division of reproductive work as integral features of the contemporary international economy'.Yeates promotes further theoretical elaborations on the 'global care chain' in order to make this concept into a real model for understanding the globalisation of care services and of the service economy in general. In so doing, she emphasises the importance of strengthening the linkages between the concept of 'global care chain' and the concept of 'global commodity chain', at least at the theoretical level. The challenge, for Yeates, is to go beyond the case of migrant domestic and care workers to look at more actors - especially corporate care providers - and forms of outsourcing service work, depending on what prevails in each context and historical period. This hypothesis looks particularly fertile for understanding phenomena emerging in the aftermath of the global economic crisis, such as the transnational recruitment of nurses and doctors due to the privatisation of what used to be publicly provided health and care services in most industrialised countries now in search of a cheap, flexible and yet highly skilled workforce (Connell 2008; Yeates 2004; Näre and Nordberg 2016; Kingma 2007).

Let me conclude by summarising that in this section I have offered the example of how gender can been understood, at the qualitative level, as something that helps us see migration and globalisation in a new perspective. As human life in general is gendered, also migration as such is affected by existing gendered constructions, which do not affect only women but also people and social relations overall. This holds true at the individual level, when looking at migrants' experiences, but also at the macro level, when wanting to understand how global migrations work.

In the following and final section, I am offering what I see as some possible examples of the auspicated directions for a new phase of feminist scholarship on migration and globalisation. 


\section{CONCLUSIONS AND NEW DIRECTIONS}

In this chapter, I outlined the relevance of a gender perspective for issues of migration and globalisation. I argued how it is important to talk about the feminisation of migration by making a distinction between a quantitative approach and a qualitative one, which can be further articulated between a subjective and a structural level. For the latter, I have illustrated the relevance of the notion of social reproduction, which scholars see has a sphere of inequality and differentiation between women at the global level, and therefore as a reason for south-north female migrations.

In the chapter's second part, I provided a short historical overview of how the research on 'gender and migration' has taken shape through time and emerged from the shadows of enquiry to become the highly visible topic of today. I concluded with a remark on the selfreflective attitude of this scholarship in recent times, and thus auspicated for an expansion of a feminist approach to migration towards other objects of analysis seen today by many scholars as a necessary completion towards the aims of this body of literature.

As a first example, it is hoped this scholarship will further incorporate studies on migrant men and masculinity. Several authors have already drawn attention to the fact that 'gender' does not embrace men as much as women, and this must be taken up by migration scholars investing more attention in male migration. A number of studies already exist that look at the importance of migration for young and adult men and how ideals of masculinity, linked to fatherhood and compulsory breadwinning models, influence their migratory projects (Gallo and Scrinzi 2016; Hearn et al. 2013; Donaldson et al. 2012).

Another important issue is how sexuality impacts on migration, which ultimately advocates for blurring the theoretical distinctions between 'sex' and 'gender' when it comes to migration research. The importance of sexuality for migration has been highlighted by scholars working on migration of transsexual and homosexual people, especially when their sexual behaviour and sexual orientation is central to their migratory experience, as for example in the case of trans people in prostitution or homosexuals applying for asylum because of the persecution they face in their countries (Cantú et al. 2009; Mai 2013).

Finally, the third element I would like to point out is the necessity to overcome the distinctions between domestic, care and sex work, in their different forms, in the analysis of migration and the international division of reproductive work. To date, scholars working on migrant domestic work, migrant sex workers and migration in care work (that is, migrant caregivers and nurses) have participated in quite different academic circles with different journals, conferences and so forth. This division, however, is in contrast to the continuity that exists between these three different jobs on two levels: first, in the experience of the migrants themselves, who may shift from one job to the other in different moments; and, second, in the theoretical tools that scholars have used to analysed them, in their different fields, and which could be profitably adapted from one to the other.

\section{NOTES}

1. Numbers vary across the world's regions. In absolute numbers, international women's migration did not increase very much in Latin America and the Caribbean (2.7 million in 1960, 2.9 in 2000) or in Asia, where 


\section{Handbook of migration and globalisation}

it was already quite high (13.5 million in 1960, 18.9 million in 2000). But it did increase significantly in Africa (from 3.7 in 1960 to 7.5 million in 2000), in Europe (from 6.7 million in 1960 to 16.7 in 2000), North America (from 6.2 million in 1960 to 20.5 million in 2000) and Oceania (from 0.9 million in 1960 to 2.9 million in 2000). Data from Table 2, page 10, of United Nations 2006.

2. In the case of Southeast Asia, earlier work is represented by Nicole Constable (1997) and Brenda Yeoh and Shirlena Huang (1998).

\section{REFERENCES}

Agustín, L. M. (2007), Sex at the Margins: Migration, Labour Markets and the Rescue Industry. London: Zed Books.

Ambrosini, M. (2013), Irregular Migration and Invisible Welfare. Basingstoke: Palgrave Macmillan.

Andall, J. (2000), Gender, Migration and Domestic Service: The Politics of Black Women in Italy. Aldershot: Ashgate.

Anderson, B. (2000), Doing the Dirty Work? The Global Politics of Domestic Labor. London: Zed Books.

Anderson, B. and R. Andrijasevic (2008), 'Sex, slaves and citizens: The politics of anti-trafficking', Soundings, 40, $135-45$.

Andrijasevic, R. (2010), Migration, Agency and Citizenship in Sex Trafficking. Basingstoke: Palgrave Macmillan.

Anthias, F. (1992), Ethnicity, Class, Gender and Migration. Aldershot: Avebury.

Baldassar, L. (1997), 'Home and away: migration, the return visit and "transnational" identity', Communal Plural Home, Displacement, Belonging, 5, 69-94.

Basa, C., V. De Guzman and S. Marchetti (2012), 'International migration and over-indebtedness: The case of Filipino workers in Italy', International Institute for Environment and Development-Human Settlements, Working Paper 36.

Basu, A., I. Grewal, C. Kaplan and L. Malkki (2001), 'Editorial', Signs: Journal of Women in Culture and Society, 26, 943-48.

Benería, L. (1979), 'Reproduction, production and the sexual division of labour', Cambridge Journal of Economics, 3, 203-25.

Bonifacio, G. T. (2012), Feminism and Migration. Dordrecht: Springer.

Boris, E. and R. S. Parreñas (2010), Intimate Labors: Cultures, Technologies, and the Politics of Care. Stanford: Stanford University Press.

Boserup, E. and N. Kanji (2007), Woman's Role in Economic Development. London: Earthscan.

Cantú, L., N. A. Naples and S. Vidal-Ortiz (2009), The Sexuality of Migration: Border Crossings and Mexican Immigrant Men. New York: New York University Press.

Chant, S. (1992), Gender and Migration in Developing Countries. London: Belhaven Press.

Connell, J. (2008), The Global Health Care Chain: From the Pacific to the World. New York/London: Routledge. Constable, N. (1997), Maid to Order in Hong Kong: Stories of Filipina Workers. Ithaca: Cornell University Press.

Constable, N. (2016), 'Reproductive labor at the intersection of three intimate industries: Domestic work, sex tourism, and adoption', Positions, 24, 45-69.

Cox, R. (2006), The Servant Problem: The Home Life of a Global Economy. London/New York: Tauris.

Da Roit, B. (2010), Strategies of Care: Changing Elderly Care in Italy and the Netherlands. Amsterdam: Amsterdam University Press.

Dalla Costa, M. and S. James (1973), The Power of Women and the Subversion of the Community. Bristol: Falling Wall Press.

Davis, K. (2008), 'Intersectionality as buzzword', Feminist Theory, 9, 67-85.

De Clementi, A. (2002), 'Gender relations and migration strategies in the rural Italian south: Land, inheritance, and marriage market', in D. Gabaccia and F. Iacovetta (eds), Women, Gender and Transnational Lives: Italian Workers of the World. Toronto: University of Toronto Press.

De Regt, M. (2009), 'Preferences and prejudices: Employers' views on domestic workers in the Republic of Yemen', Signs, 34, 559-81.

Degiuli, F. (2016), Caring for a Living: Migrant Women, Aging Citizens, and Italian Families. Oxford: Oxford University Press.

Donaldson, M., R. Hibbins, R. Howson and B. Pease (2012), Migrant Men: Critical Studies of Masculinities and the Migration Experience. New York/London: Routledge.

Donato, K. M., D. Gabaccia, J. Holdaway, M. Manalansan and P. R. Pessar (2006), 'A glass half full? Gender in migration studies', International Migration Review, 40, 3-26.

Douglass, M. (2006), 'Global householding in Pacific Asia', International Development Planning Review, 28, 421-45. 
Dwyer, C. (1999), 'Contradictions of community: Questions of identity for young British Muslim women', Environment and Planning, 31, 53-68.

Ehrenreich, B. and A. R. Hochschild (eds) (2002), Global Woman: Nannies, Maids and Sex Workers in the New Economy. London: Granta.

Ellis, M., D. Conway and A. J. Bailey (1996), 'The circular migration of Puerto Rican women: towards a gendered explanation', International Migration, 34, 31-64.

Enloe, C. (1989), Bananas, Beaches and Bases. London: Pandora Press.

Ferreira, V., T. Tavares and S. Portugal (eds) (1998), Shifting Bonds, Shifting Bounds: Women, Mobility and Citizenship in Europe. Oeiras: Celta Editora.

Folbre, N. (2001), The Invisible Heart: Economics and Family Values. New York: New Press.

Gabaccia, D. R. (1994), From the Other Side: Women, Gender, and Immigrant Life in the US, 1820-1990. Bloomington: Indiana University Press.

Gallo, E. and F. Scrinzi (2016), Migration, Masculinities and Reproductive Labour: Men of the Home. New York: Springer.

Gutiérrez-Rodríguez, E. (2010), Migration, Domestic Work and Affect: A Decolonial Approach on Value and the Feminization of Labor. London: Routledge.

Hearn, J., M. Blagojevic and K. Harrison (2013), Rethinking Transnational Men: Beyond, Between and Within Nations. London: Routledge.

Herrera, G. (2013), 'Lejos de tus pupilas', Familia transnacionales, cuidados y desigualdad social en Ecuador. Quito: FLACSO.

Hochschild, A. R. (2002), 'Love and gold', in B. Ehrenreich and A. R. Hochschild (eds), Global Woman: Nannies, Maids, and Sex Workers in the New Economy. New York: Holt.

Hoerder, D., E. Van Nederveen and S. Neunsinger (2015), Towards a Global History of Domestic and Caregiving Workers. Leiden: Brill.

Hondagneu-Sotelo, P. (1999), 'Introduction gender and contemporary US immigration', American Behavioral Scientist, 42, 565-76.

Hondagneu-Sotelo, P. (2001), Doméstica: Immigrant Workers Cleaning and Caring in the Shadows of Affluence. Berkeley: University of California Press.

ILO (2013), Domestic Workers across the World: Global and Regional Statistics and the Extent of Legal Protection. Geneva: ILO.

Kabeer, N. (2003), Gender Mainstreaming in Poverty Eradication and the Millennium Development Goals: $A$ Handbook for Policy-Makers and Other Stakeholders. London: Commonwealth Secretariat.

Kingma, M. (2007), 'Nurses on the move: A global overview', Health Services Research, 42, 1281-98.

Kofman, E. (2012), 'Rethinking care through social reproduction: Articulating circuits of migration', Social Politics, 19, 142-62.

Kofman, E. and P. Raghuram (2015), Gendered Migrations and Global Social Reproduction. Basingstoke: Palgrave Macmillan.

Land, P.-C. (2006), Global Cinderellas: Migrant Domestic Workers and Newly Rich Employers in Taiwan. Durham, NC/London: Duke University Press.

Lutz, H. (2011), The New Maids: Transnational Women and the Care Economy. London: Zed Books.

Mahler, S. J. and P. R. Pessar (2001), 'Gendered geographies of power: Analyzing gender across transnational spaces', Identities: Global Studies in Culture and Power, 7, 441-59.

Mai, N. (2013), 'Embodied cosmopolitanisms: The subjective mobility of migrants working in the global sex industry', Gender, Place and Culture, 20, 107-24.

Marx-Ferree, M. (1979), 'Employment without liberation: Cuban women in the United States', Social Science Quarterly, 60, 35-50.

Massey, D. (1994), Space, Place and Gender. Cambridge: Polity.

McCall, L. (2005), 'The complexity of intersectionality', Signs, 30, 1771-800.

McDowell, L. (1999), Gender, Identity and Place: Understanding Feminist Geographies. Minneapolis: University of Minnesota Press.

Meyer, M. K. and E. Prügl (1999), Gender Politics in Global Governance. Lanham, MD: Rowman \& Littlefield.

Momsen, J. (1999), 'Maids on the move', in J. Momsen (ed.), Gender, Migration and Domestic Service. London: Routledge.

Morokvaśic, M. (1984), 'Birds of passage are also women', International Migration Review, 18, 886-907.

Nakano-Glenn, E. (2002), Unequal Freedom: How Race and Gender Shaped American Citizenship and Labor. Cambridge, MA/London: Harvard University Press.

Näre, L. and C. Nordberg (2016), 'Neoliberal postcolonialism in the media: Constructing Filipino nurse subjects in Finland', European Journal of Cultural Studies, 19, 16-32.

O'Connell Davidson, J. (2005), Children in the Global Sex Trade. Cambridge: Polity.

O'Leary, E. L. (1996), At Beck and Call: The Representation of Domestic Servants in Nineteenth-Century American Paintings. Washington DC: Smithsonian Institution. 


\section{Handbook of migration and globalisation}

Oakley, A. (1975), The Sociology of Housework. New York: Pantheon.

Okin, S.M. (1999), Is Multiculturalism Bad for Women? Princeton: Princeton University Press.

Ong, A. (1999), Flexible Citizenship: The Cultural Logics of Transnationality. Durham, NC: Duke University Press.

Oso, L. and N. Ribas-Mateos (2013), The International Handbook on Gender, Migration and Transnationalism. Cheltenham, UK and Northampton, MA, USA: Edward Elgar Publishing.

Özyeğin, G. (2010), Untidy Gender: Domestic Service in Turkey. Philadelphia: Temple University Press.

Palmer, P. (1989), Domesticity and Dirt: Housewives and Domestic Servants in the United States, 1920-1945. Philadelphia: Temple University Press.

Parreñas, R. S. (2000), 'Migrant Filipina domestic workers and the international division of reproductive labor', Gender \& Society, 14, 560-80.

Parreñas, R. S. (2001), Servants of Globalization: Women, Migration and Domestic Work. Stanford: Stanford University Press.

Parreñas, R. S. (2005), Children of Global Migration: Transnational Families and Gendered Woes. Stanford: Stanford University Press.

Parreñas, R. S. (2009), 'Inserting feminism in transnational migration studies', Migrationonline.cz, 22 May, at http://migrationonline.cz/en/inserting-feminism-in-transnational-migration-studies.

Pessar, P. R. (1984), 'The linkage between the household and workplace of Dominican Women in the US', International Migration Review, 18, 1188-211.

Petersen, S. V. (2003), A Critical Rewriting of Global Political Economy: Integrating Reproductive, Productive and Virtual Economies. London/New York: Routledge.

Piore, M. J. (1980), Birds of Passage: Migrant Labor and Industrial Societies. Cambridge: Cambridge University Press.

Piper, N. (2013), New Perspectives on Gender and Migration: Livelihood, Rights and Entitlements. London: Routledge.

Pratt, G. (2012), Families Apart: Migrant Mothers and the Conflicts of Labor and Love. Minneapolis: University of Minnesota Press.

Radcliffe, S. A. (1991), 'The role of gender in peasant migration: Conceptual issues from the Peruvian Andes', Review of Radical Political Economics, 23, 129-47.

Ray, R. and S. Qayum (2009), Cultures of Servitude: Modernity, Domesticity, and Class in India. Stanford: Stanford University Press.

Rollins, J. (1985), Between Women: Domestics and their Employers. Philadelphia: Temple University Press.

Romero, M. (1992), Maids in the U.S.A. New York/London: Routledge.

Salih, R. (2003), Gender in Transnationalism: Home, Longing and Belonging among Moroccan Migrant Women. New York/London: Routledge.

Sarti, R. (2002), Europe at Home: Family and Material Culture, 1500-1800. New Haven: Yale University Press.

Sassen, S. (2000), 'Women's burden: Counter-geographies of globalization and the feminization of survival', Journal of International Affairs, 53, 503-24.

Sassen, S. (2002), 'Global cities and survival circuits', in B. Ehrenreich (ed.), Global Woman: Nannies, Maids and Sex Workers in the New Economy. New York: Holt.

Schrover, M. and E. Yeo (2011), Gender, Migration, and the Public Sphere, 1850-2005. New York/London: Routledge.

Silvey, R. (2004), 'Power, difference and mobility: Feminist advances in migration studies', Progress in Human Geography, 28, 490-506.

Solari, C. (2010), 'resource drain vs. constitutive circularity: Comparing the gendered effects of post-Soviet migration patterns in Ukraine', Anthropology of East Europe Review, 28, 215-38.

Timonen, V. (2008), Ageing Societies: A Comparative Introduction. New York: Open University Press.

Triandafyllidou, A. (2016), Irregular Migrant Domestic Workers in Europe: Who Cares? New York/London: Routledge.

Truong, T.-D. (1996), 'Gender, international migration and social reproduction: Implications for theory, policy, research and networking', Asian and Pacific Migration Journal, 5, 27-52.

United Nations (2006), 2004 World Survey on the Role of Women in Development: Women and International Migration. New York: United Nations.

Van Walsum, S. (2011), 'Regulating migrant domestic work in the Netherlands: Opportunities and pitfalls', Canadian Journal of Women and the Law/Revue Femmes et Droit, 23, 141-65.

Vianello, F. A. (2014), 'Ukrainian migrant workers in Italy: Coping with and reacting to downward mobility', Central Eastern European Migration Review, 3, 85-98.

Williams, F. (2012), 'Converging variations in migrant care work in Europe', Journal of European Social Policy, 22, 363-76.

Wolkowitz, C. (2006), Bodies at Work. London: Sage. 
Yeates, N. (2004), 'Global care chains', International Feminist Journal of Politics, 6, 369-91.

Yeoh, B. S. and S. Huang (1998), 'Negotiating public space: Strategies and styles of migrant female domestic workers in Singapore', Urban Studies, 35, 583-602.

Zelizer, V. A. (2009), The Purchase of Intimacy. Princeton: Princeton University Press. 